\title{
India's "Tïrthas": "Crossings" in Sacred Geography
}

\section{Citation}

Eck, Diana L. 1981. India's "Tīrthas": "Crossings" in sacred geography. History of Religions 20 (4): 323-344.

\section{Published Version}

http://www.jstor.org/stable/1062459

\section{Permanent link}

http://nrs.harvard.edu/urn-3:HUL.InstRepos:25499831

\section{Terms of Use}

This article was downloaded from Harvard University's DASH repository, and is made available under the terms and conditions applicable to Other Posted Material, as set forth at http:// nrs.harvard.edu/urn-3:HUL.InstRepos:dash.current.terms-of-use\#LAA

\section{Share Your Story}

The Harvard community has made this article openly available.

Please share how this access benefits you. Submit a story.

Accessibility 


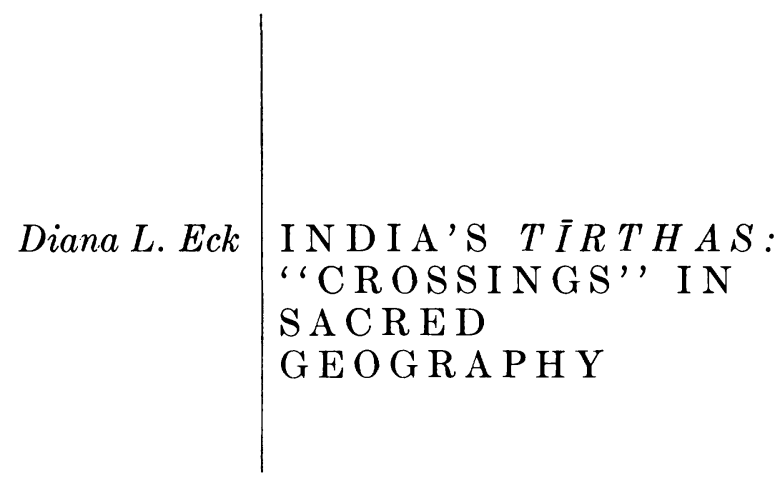

One of the oldest strands of the Hindu tradition is what one might call the "locative" strand of Hindu piety. Its traditions of ritual and reverence are linked primarily to place- to hilltops and rock outcroppings, to the headwaters and confluences of rivers, to the pools and groves of the forests, and to the boundaries of towns and villages. In this locative form of religiousness, the place itself is the primary locus of devotion, and its traditions of ritual and pilgrimage are usually much older than any of the particular myths and deities which attach to it. In the wider Hindu tradition, these places, particularly those associated with waters, are often called tìrthas, and pilgrimage to these tīrthas is one of the oldest and still one of the most prominent features of Indian religious life. A tīrtha is a "crossing place," a "ford," where one may cross over to the far shore of a river or to the far shore of the worlds of heaven. Hence, tìrtha has come to refer to these places of pilgrimage, where the crossing might be safely made. This is a study of the meanings of the word tīrtha in its Vedic and Sanskrit usages

This paper was originally presented at a conference in honor of Wilfred Cantwell Smith, held at the Center for the Study of World Religions, Harvard University, June 15-17, 1979.

(C) 1981 by The University of Chicago. 0018-2710/81/2004-0002\$01.00 
and the elaboration of the notion of tirtha in the locative ritual traditions of Hinduism.

\section{THE RIVER AND THE CROSSING}

The river is an ancient and complex cultural symbol in India. India's oldest civilization was a river culture on the Indus, and in the hymns of the invading Aryans as well, this particular river, called the Sindhu, is highly praised. She is one of the seven "mother-rivers," a group which has changed through time to include such rivers as the Ganga and the Narmad $\bar{a}$, but which in Vedic times referred to the Sindhu, the Sarasvati, and the "Five Rivers" of the Punjab, all in the northwest. Crossing the great rivers of India, especially in their season of full flood, has long been a challenge to travelers, who have sought out the fords with their ferries and rafts to make a safe crossing. Samsāra, the ceaseless flow of birth and death and birth again, was likened to a river, and the far shore became an apt and powerful symbol of the goal of the spiritual traveler as well: the indistinct horizon of sure ground on the far side of the flood, beyond the treacherous currents.

The Vedic imagination produced two great images of crossing the river flood. First, since the universe is fundamentally three storied, with the heavens above, the atmosphere in the middle, and the earth below, one crosses over from earth to heaven or, in the case of the gods, from heaven to earth. The atmosphere (antarikșa), extending as far up as the blue extends, is often described as a vast river of space to be forded in the communication between heaven and earth. The second image is related: India's rivers are seen as originating in heaven and flowing vertically from the lake of divine waters in heaven, down through the atmosphere, and out upon the face of the earth. In the Rigvedic myth, Indra slays the serpent Vrtra, who had coiled around the heavens and locked the waters inside, and frees the heavenly waters to fall to earth.

As your ally in this friendship, Soma,

Indra for man made the waters flow.

He slew the serpent and sent forth the Seven Rivers.

He opened, as it were, the holes that were blocked. ${ }^{1}$

${ }^{1}$ F. Max Müller, ed., Rig-Veda-Sanhita: The Sacred Hymns of the Brahmans, Together with the Commentary of Sayanacharya (London: W. H. Allen \& Co., 1849-74); Sripad Sharma, ed., Rg Veda Samhitā (Aundha: Svādhyāyamañạala, 1940), 4.28.1. Consultation with Ralph T. H. Griffiths, trans., The Hymns of the Rig Veda (1889; reprint ed., Delhi: Motilal Banarsidass, 1973). 
This flow of life-giving waters which links heaven and earth becomes a means for crossing, for by those waterfall rivers one may cross from earth to the far shore of heaven. The Ganga for instance, is sometimes called svarga-sopanna-sarin̄i, "the flowing ladder to heaven."

Since crossing to the far shore may be a crossing up as well as a crossing over, both the image of the ladder (sopāna) and that of the bridge (setu) are utilized in the symbolic vocabulary of transcendence. However, the term that is most elaborately developed in the language of the crossing is tìrtha.

The word tìrtha is from the Sanskrit verb $t \bar{r} /$ tarati, meaning "to cross over." The noun tìrtha means a ford, as well as any watering or bathing place. It sometimes means a path or passage more generally. The root verb $t \bar{r}$ includes subsidiary meanings - to master, to surmount, to fulfill, to be saved - as well as its primary meaning, to cross. The noun tāraka, also derived from $t \bar{r}$, means a boat or ferry, as well as a pilot or savior. Tìrtha, with its many associations, is a word of passage. It refers not to the goal, but to the way, the path one travels. The word is especially interesting for developing a comparative vocabulary of "passage" because it belongs to a whole family of Indo-European cognates which are the great words of passage and pilgrimage in the West: through, durch, and trans, as prepositions, and all of the many passage words related to them, which in English alone include thoroughfare, transition, transform, transport, and transcend. ${ }^{2}$

In India today the word tirtha is associated primarily with those crossing places which are places of pilgrimage and which bring the traditions of the gods and goddesses, heroes, heroines, and sages to living embodiment in India's geography. Even the most famous tìrthas which attract pilgrims across linguistic, sectarian, and regional boundaries number in the hundreds. In addition, there are the countless local and regional tīrthas visited regularly by pilgrims from their immediate areas. No place is too small to be counted a tirtha by its local visitors. In a sense, each temple is a tīrtha, especially consecrated as a crossing place between heaven and earth. ${ }^{3}$

2 Julius Pokorny, Indo-germaniches etymologisches Wörterbuch (Bern: Francke, 1948-59); Manfred Mayrhofer, A Concise Etymological Sanskrit Dictionary (Heidelberg: Carl Winter, 1953-76); Jacob Wackernagel and Albert Debrunner, Altindische Grammatik, vol. 2, pt. 2 (Göttingen: Vandenhoeck \& Ruprecht, 1954); Eric Partridge, A Short Etymological Dictionary of Modern English (New York: Macmillan Publishing Co., 1966).

${ }^{3}$ For the temple/tirtha homology, see Stella Kramrisch, The Hindu Temple (1946; reprint ed., Delhi: Motilal Banarsidass, 1976), pp. 3-17. 
The phenomenon of pilgrimage to such charged places was firmly grounded in the ancient locative folk traditions of the yakșas and nāgas. Only later do we find brahmanical traditions of pilgrimage to these places, that is, in the time of the Mahābhārata and the subsequent era of the early Purānas. And only then does the word tirtha come to refer explicitly to these places of pilgrimage. By that time, however, the word complex tìrtha/tarati already had a considerable history. Uncovering some of the contours of the use of these words in Vedic and Upanisadic sources, through a kind of archaeology of the word, will enable us to see more accurately the force this notion of tìrtha brings with it when it comes to popular use as a place of pilgrimage in the epics, Purāṇas, and Dharmaśāstras.

THE PLACE OF CROSSING: THE NOUN Tîrtha

From the various usages of the noun tìrtha in the Vedic Samhitās, Brāhmañas, and Upanișads, one can outline the variety of things it did mean as well as get a clear sense of what it did not mean. ${ }^{4}$ It did not mean, for example, a place of pilgrimage. But it did have associations with purity and ritual which helped to shape the understanding of tîrtha in later times.

One constellation of tirtha meanings is related directly to the river. It is a crossing place and, conversely, a landing place on the riverbank. It is associated with good waters for drinking and for bathing.

It is a tirtha of good drinking water for which one hymnist entreats the Aśvins, the twin gods of the dawn: "Make a tīrtha, Lords of splendour, for good drinking!"' Elsewhere the hymnist, praising Indra, says that the sacrifice invites him, awaits him, "as pleasure at the tìrtha invites one who is thirsty." 6

In the Vedic literature the good waters of the tìrtha are charged with the nourishing and purifying power which came later to be associated with the River Gangā. After all, the seven rivers released from heaven by Indra are identified with Soma, the nourishing, intoxicating drink of the gods. The

\footnotetext{
${ }^{4}$ Vishva Bandu, ed., A Vedic Word Concordance, rev. and enlarged ed. (Hoshiarpur: Vishveshvaranand Vedic Research Institute, 1976); G. A. Jacob, $A$ Concordance to the Principal Upanisads and the Bhagavad Gita (1891; reprint ed., Delhi: Motilal Banarsidass, 1971).

${ }^{5}$ Rg Veda 10.40.13.

6 Ibid., 1.173.11.
} 
ritual plant Soma, when it is pressed through the woolen filter, falls into the wooden collecting vat below. Falling, it is called Soma Pavamāna, the "Purifying Soma," which is praised in a great number of hymns in the ninth book of the Rg Veda. The pressed Soma, flowing into the wooden vat, is likened to the swift-flowing Sindhu, running both with water and with milk. ${ }^{7}$ This homology of falling Soma, falling rivers, and falling milk is well known. In some hymns, it is not the divine rivers but the mother cows, yielding divine milk, who are released from the heavenly pen by Indra. Like milk and like Soma, tīrtha waters are called "strength and sap." In one hymn, the Soma itself is said to flow with purity to the "famed tîrtha." The shared symbolic structure of the tìrtha waters and the poured Soma is seen again, for example, in Rg Veda 10.31.3, where the Soma is poured and friends come to the wonderful drink "as to a tìrtha." In sum, the heavenly streams which fall to become the rivers of earth are, in the Vedic imagination, the streams of Soma, pressed through the filter of heaven. The later myth of the descent of the river Ganga clearly repeats this imaginative structure, and the Ganga $\bar{a}$ too is said to flow with milk and with amrta, the nectar of immortality.

In addition to being a place of good drinking, the tirrtha was apparently a place of bathing as well. For example, in the Taittirīya Samhitā the priest of the Soma sacrifice is said to bathe in a tĩrtha: "The Angirases going to the world of heaven placed in the waters consecration and penance. He (the priest of the Soma sacrifice) bathes in the waters; verily visibly he secures consecration and penance. He bathes at a tìrtha, for at a tirtha did they place (consecration and penance); he bathes at a tìrtha; verily he becomes a tìrtha for his fellows. He sips water; verily he becomes pure within." 10 Here bathing in the tirtha is an act of penance and purification in preparation for ritual. This becomes a familiar theme in the later tîrtha tradition. Especially interesting in this passage is the fact that the one who is thus purified becomes a tìrtha for others. Here, as in the emerging Jaina tradition as well, the word tîrtha is

7 Ibid., 9.97.45.

${ }^{8}$ Kaușītaki Brāhmana (Śañkhāyana Brāhmana), Ānandāśrama Sanskrit Series 65 (Poona, 1911), 12.i; Arthur B. Keith, trans., Rig-Veda Brāhmanas, Harvard Oriental Series, vol. 25 (Cambridge, Mass.: Harvard University Press, 1920).

${ }^{9} \mathrm{Rg}$ Veda 9.97.53.

10 Arthur B. Keith, trans., Taittirīya Samhitā of the Black Yajur Veda, Harvard Oriental Series, vols. 18 and 19 (Cambridge, Mass.: Harvard University Press, 1914), 6.1.1.2-3. 
used not only of a place but also of a person who may become a crossing for others.

A second group of tīrtha meanings emphasizes the nature of the tirtha as limens: the threshold, betwixt and between, which links this world and the other. The liminal nature of the tìtha is made clear in one hymn which compares time's thresholds - the twin twilights of dawn and dusk-with tìrthas. When, it is asked, is the best time of the Agnihotra fire offering? "At the twilight should he offer. Night and day are the flood that takes all; the two twilights are the tìrthas of it; just as a man may cross [taret] the flood by the two tìrthas, so it is that he should offer at the twilight." "11 In the Satapatha Brāhmana, the introductory and concluding rites of the year-long Soma sacrifice are called its tirthas, the "steps" by which one enters the "ocean" of the ritual at its outset and leaves it again at its conclusion. ${ }^{12}$

In another hymn, the devout singer invites the Aśvins to mount the chariot which stands at the heavenly tirtha on the shore of the lake of Soma, and he asks the Aśvins to cross over to this shore on a boat made of his own hymns. ${ }^{13}$ In sum, it is clear that the tīrtha is not only a riverside bathing and watering place, but a place where one launches out on the journey between heaven and earth. It is a threshold of time, or space, or ritual.

Finally, it is not surprising to find a cluster of tìrtha usages in the early tradition which have to do with the Vedic sacrifice itself. After all, the purpose of the sacrifice was, in part, to bring about the communication, the linking, of this world and the other. In this context, the tìrtha is the path which both the priests and the gods take to the uttaravedi altar for the drinking of Soma. It is called the apnanna path and the "tìrtha of the gods." "14 "Who here hath proclaimed the A pnãna tīrtha?' Having approached the sacrifice by this tirtha, they obtained all desires. Verily thus also the sacrificer by this tìrtha having approached the sacrifice obtains all desires." 15

Structurally, one might view the entire sacrifice as a tīrtha,

${ }^{11}$ Kauşitaki Brāhmaṇa 2.9.

12 Albrecht Weber, ed., The Chatapatha Brāhmana (The White Yajur Veda, pt. 2) (London: Williams \& Norgate, 1855), 12.2.1.1.1-5; Julius Eggeling, trans., Satapatha Brāhmana: The Sacred Books of the East, vols. 12, 26, 41, 43, and 44 (Oxford: Clarendon Press, 1882-1900).

${ }_{13} \mathrm{Rg}$ Veda 1.46.7-8.

14 Ibid., 10.114.7.

${ }^{16}$ Kaușitaki Brāhmaṇa 18.9. 
as a crossing place where all the elements of this world are brought together in symbolic microcosm for the vertical crossing of the sacrificer to heaven. The sacrifice is not directly called a tirtha in Vedic literature, but it is clear that the symbolic syntax of the later tivtha as well as that of the later temple share the sacrificial paradigm: the intensification and condensation of the constituents of this world in a powerful center, from which this world might be transcended and linked with the worlds of heaven.

\section{THE ACT OF CROSSING: THE VERB Tarati}

The meaning of the noun tîrtha in the literature under consideration is enhanced by looking at the uses of its verbal root $t \bar{\varphi} /$ tarati, to cross. In a few cases the verb takes its subsidiary meanings - to conquer, to subdue, to surpass. For example, Indra subdues Vṛtra; ${ }^{16}$ the falcon surpasses the wind $;^{17}$ or Soma overtakes adversities. ${ }^{18}$ Occasionally, the verb means "crossing" in a mundane sense, as in Satapatha Brāhmaṇa 1.4.1.14, where "the Brāhmañas did not cross the Sadānīā river. ..." However, a great number of the usages of tarati in the Saṃhitās and Brāhmañas and virtually all of its usages in the Upanișads have to do with crossing in a ritual or a spiritual sense.

First, in the ritual context, this verb of passage is aptly associated with the sacrifice and its crossings both hither and yon, from earth to heaven or, in the case of the gods, from heaven to earth. Soma, for instance, is entreated to come, bringing cows, wealth, and progeny; to come from the waters, the plants, and the pounding boards; to cross over (tara) all trouble, and to sit upon the sacrificial strew. ${ }^{19}$ In the Aitareya Brāhmana, the wind Vāyu is said to cross (tarati) the whole universe, like a runner carrying the offering to the gods. ${ }^{20}$ Elsewhere, the hymns of the sacrifice are called the two ships which carry the sacrifice to the other shore. By them the sacrificers cross over (taranti) the year, just as one crosses a river. ${ }^{21}$ Similarly, another poet wishes to ascend by means of

${ }^{16}$ Taittīina Brāhmana of the Krșna Yajur Veda, Ānandāśrama Sanskrit Series 37 (Poona, 1898), 3.1.2.1.

${ }_{17} \mathrm{Rg}$ Veda 4.21.2.

18 Ibid., 9.96.15.

${ }^{19}$ Ibid., 9.59.3.

${ }_{20}$ Aitareya Brāhmana, with the Commentary of Sāyaṇa, Ānandāśrama Sanskrit Series 32 (Poona, 1896), 2.34; Keith, trans., Rig-Veda Brähmanas.

${ }^{21}$ Aitareya Brăhmaṇa 4.13. 
his hymns to the heavenly ocean, where the Sun tethers his horses. "May we cross over [tuturyāma] safely with this hymn," he asks. ${ }^{22}$

The gods are the ones who most frequently make the crossing from heaven to earth, from earth to heaven. Both Soma and Agni descend and ascend, manifesting their divine presence in both heaven and earth. Soma, the milk of heaven, is present on earth in the milk of rivers and in the sap of plants. Agni, the fire of heaven, descends to earth in the sacrificial fire. Ușas, the dawn at the threshold of night and day, is also a crosser by nature, reaching out daily with the rays of her own radiance, crossing the waters and touching the hills..$^{23}$ Likewise, Sūrya, the sun, is called the bridge (setu), since his rays span the sea of space between heaven and earth. ${ }^{24}$ Rudra, who more than any other becomes the lord of the tīrthas in the later tradition, is also one who crosses back and forth, as is seen in this passage from the Taittiríya Samhitā:

Homage to him of the ford [tîrthyāya] and to him of the bank.

Homage to him beyond and to him on this side.

Homage to him who crosseth over [prataranāya] and to him who crosseth back [uttaranāya].

Homage to him of the crossing [ātāryāya] and to him of the ocean. ${ }^{25}$

The dynamics of these divine crossings of the gods from heaven to earth are elaborated in the post-Vedic era in the notion of avatära, the divine descents. The word is formed from the root $t \bar{r}$ plus the prefix ava: to "cross downward." The descents of Viṣnu, for instance, are well known. We shall return below to the significance of the interplay between avatāra and tìrtha.

In the Upanișads the verb $t \bar{r}$ is used almost exclusively to refer to the spiritual crossing from the realm of birth and death to immortality, from ignorance to knowledge, from darkness to light. This usage is not without precedent in the earlier Vedic literature, however, where occasionally "crossing over" means leaving behind this world of trouble, old age, and death. In Rg Veda 10.31.1, for example, the poet opens with a prayer that the benedictions of the gods may come near and that by these benedictions we may cross over (taranto) all our troubles.

${ }^{22} \mathrm{Rg}$ Veda 5.45.11.

${ }^{23}$ Ibid., 6.64.4; the verb in this verse is tarasi.

${ }^{24}$ Ibid., 10.61.16.

${ }^{25}$ Taittirìya Sampitā 4.5.8. 
Similarly, Rg Veda 10.27.21 speaks of those who cross beyond (taranto) this realm of old age to a place of glory where there is no sorrow. The Taittirīya Brāhmana speaks of the purified man who crosses over (tarati) sins and prays that we, purified by that man, may likewise cross beyond (tarema) sins. ${ }^{26}$ Elsewhere in the same text the sacrificer prays that he may cross beyond (tarāmi) death. ${ }^{27}$

The act of crossing in the Upanișads is a spiritual transition and transformation from this world to what is called the world of Brahman, the world illumined by the light of knowledge. It is a crossing which must be made with the aid of a guide, a guru, and by means of the knowledge he imparts. The Praśna Upanișad 6.8, for instance, ends with the students' praise of their guru Pippalāda: "You truly are our father-you who lead us across to the shore beyond ignorance [param pāram tärayasi]." ${ }^{28}$ In the Iśa Upanișad a person, passing over $(t \bar{\imath} r t \bar{a})$ death, gains immortality (amrtam) by virtue of knowledge. ${ }^{29}$ In the Mundaka Upanișad, sorrow and sin are crossed over to reach immortality. The knower of Brahman, it is said, becomes Brahman. "He crosses over [tarati] sorrow. He crosses over [tarati] sin. Liberated from the knots of the heart, he becomes immortal.", 30

The near shore left behind is characterized by the distinctions of good and evil, birth and death, hunger and thirst, day and night-the dualities (dvandvas) of samsarra. The far shore ( $p \bar{a} r a)$ is without these dualities. In the Katha Upanișad 1.12, Naciketas, in his conversation with Death, describes the world of heaven as a place where one rejoices, having crossed beyond $(t \bar{r} r t v \bar{a})$ both old age and death, hunger and thirst. Death teaches the deepest meaning of the fire sacrifice to Naciketas and explains that whoever kindles the triple fire and performs the three acts (Śankara indicates that the three are sacrifice, study, and almsgiving) crosses over (tarati) birth and death. Later on in Kațha 3.2, this "Naciketas fire" is called "the bridge [setu] for those who sacrifice" and is described as the "highest imperishable Brahma for those who seek to cross over [titîrşatām] to the fearless farther shore."

${ }^{26}$ Taittirīya Brāhmana 3.12.3.4.

${ }^{27}$ Ibid., 1.2.1.15.

${ }^{28}$ Pandita Jagadīśa Sāastri, ed., Upanişatsañgraha (Delhi: Motilāl Banārsīdās, 1970 ); R. E. Hume, trans., The Thirteen Principal Upanisads, 2d rev. ed. (Oxford: Oxford University Press, 1931).

${ }^{29}$ Íśa Upanișad 11.14.

${ }^{30}$ Muṇụaka Upanișad 3.2.9. 
This sense of crossing beyond the distinctions of this world is also found in Sanatkumāra's teaching to Nārada in the Chāndogya Upanișad 8.4. The teacher proposes the image of the atman as the bridge (setu) which separates the worlds: "Over that bridge there cross [taratah] neither day nor night, nor old age, nor death, nor sorrow, nor well-doing, nor evildoing. All evils turn back therefrom, for that Brahma-world is freed from evil.... Therefore, verily, upon crossing [tīrtā] that bridge, the night appears even as the day, for that Brahmaworld is ever illumined." Here the tīrtha, the crossing place or the bridge, is the atman itself. Like a bridge, it both separates and joins the near shore of dualities and the far shore in which those distinctions do not exist. It is the means for the crossing, and the crossing is an interior one.

The language of interior crossing is also used in the context of interior or yogic disciplines. For instance, in the Kausiitaki Brāhmaṇa 11.4 the means of crossing is the breath and the holy mantra called the Pranava: Om. "Breath is immortality; thus by immortality he passes by [tarati] death; just as one steps over a pit by means of a beam or a roller, so with the Pranava he steps over; the Pranava is holy power; verily thus with the holy power he continues the holy power." In 14.2 of the same text we find: "Therefore without drawing in breath should he pass over; breath is immortality; thus by immortality he crosses [tarati] death." Similarly, in the Maitri Upanișad 6.21, the crossing is that of the yogin who ascends by means of the breath and the syllable "Om" through the channel of the subtle physiology called sușumnā: "After having first caused to stand still / The breath that has been restrained, then, / Having crossed [tīrtvā] beyond the limited, with the unlimited / One may at last have union in the head." The Upanișad goes on in 6.22 to compare the yogic ascent with that of a spider ascending by means of his own thread to free space. Finally, in 6.28 , the yogin, having slain the doorkeeper called egoism and "having crossed over [tir $r t v \bar{a}]$ with the raft of the syllable $\mathrm{Om}$ to the other side of the space in the heart," enters the hall of Brahman.

In the Bṛhadāranyaka Upanișad, the one who is united with Brahman is described as in a dreamless sleep, where the categories of this shore are left behind. There, it is said, the father is not a father, the thief not a thief, the ascetic not an ascetic. "He is not followed by good, he is not followed by evil, for 
then he has passed beyond [tīrno] all sorrows of the heart." ${ }_{31}$ The one who knows the ätman as "not this, not this" crosses beyond [tarati] the world of duality. ${ }^{32}$

It would take us too far afield here to explore the ways in which these words of passage, tīrtha and tarati, have been used in the Jaina and Buddhist traditions. However, even a cursory survey of their early literature confirms that these terms were used to express profound spiritual transition. Although the earliest Jaina literature refers to the enlightened teacher as a jina, a "victor," before long he became known as a tīrthakāra or tīrthainkara, a "ford maker," who has crossed the stream and reached the far shore. In the early Buddhist literature, the term tîrtharkara, having been claimed by the Jainas, is assiduously avoided as a synonym for tathăgata. Indeed, the term tîrthaikkara was so thoroughly identified with the Jaina sages that it most commonly means "heretic" in the Buddhist context! Nevertheless, the Buddhists, without utilizing the term tìrtha, developed and enriched the spiritual image of the far shore as the goal and the language of the crossing as the way of spiritual life. The Buddhist use of $t \bar{r} /$ tarati as verbs of passage closely corresponds to the way in which these words are used in the Upanișads. The following few examples could be multiplied a hundredfold from the early Buddhist literature: "... When thou hast learned the best Dhamma, then thou shalt cross [taresi] this stream;" 33 "Give up what is before, give up what is behind, give up what is in the middle, when thou goest [taresi] to the other shore of existence; if thy mind is altogether free, thou wilt not again enter into birth and decay;" 34 "And he is a wise and accomplished man in this world; having abandoned this cleaving to reiterated existence he is without desire, free from longing, he has crossed over birth and old age, so I say." 35

\section{CROSSINGS IN THE SACRED GEOGRAPHY OF INDIA}

In the later Upanișads, the Epics, and the Purānas, the word tìrtha comes to common use as the spiritual ford which is the

${ }^{31}$ Brhadāraṇyaka Upanişad 4.3.22.

${ }^{32}$ Ibid., 4.4.22.

${ }^{33}$ V. Fausboll, trans., The Sutta Nipãta: The Sacred Books of the East, vol. 10, pt. 2 (Oxford: Clarendon Press, 1881), Pārāyanavagga 6.4.

${ }^{34}$ F. Max Müller, trans., The Dhammapada: The Sacred Books of the East, vol. 10, pt. 1 (Oxford: Clarendon Press, 1881), verse 348.

${ }_{35}$ The Sutta Nipāta, Pārāyanavagga 5.12. 
destination of pilgrims, whose tīrtha tours (tīrthayātras) come to increasing prominence in the religious life of the emerging Hindu tradition. It is important to remember that the term comes to be used as a pilgrim tīrtha in a context in which the symbolic language of the river, the ford, the crossing, and the far shore had already been developed and elaborated with great subtlety and richness.

Although the tîrtha traditions of the rising classical Hindu tradition built upon the ancient sacrificial vocabulary or crossing back and forth between heaven and earth and the Upanisadic wisdom vocabulary of crossing to the far shore, the many specific tìrthas of India's vast sacred geography are also well grounded in yet another tradition: the non-Vedic tradition of indigenous India which, despite its many areas of obscurity, was most clearly a tradition of life-force deities associated with particular places. It was a locative tradition in which genii loci under a variety of names-yakșas, nāgas, ganas, mātrikāswere associated with groves and pools, hillocks and villages, wielding power for good or ill within their areas of jurisdiction. Many of the deepest roots of India's traditions of $p \overline{u j} \bar{a}$ and tìrthayātra are here in this place-oriented cultus. Although the myths associated with these places have changed, layering one upon the other through the centuries, pilgrims have continued to come with their vows and petitions, seeking the sight (darśana) and the token material blessings (prasāda) of the deity of the place. Whether it is Mathurā or Vārānasīi, Purī or Tirupati, the ancient roots of today's great tīrthas are in the cultus of the genii loci who reigned long before their places came to be called tìrthas and long before their influence began to be co-opted by the emergence of Siva, Viṣnu, Kṛ̦ṇa, and the Goddess.

Let us now turn to the consideration of these tìrthas of the earth which have inherited both the ritual and wisdom traditions of ancient Vedic India as well as the locative traditions of her indigenous piety. The array of India's tîrthas is impressive. In this context, since we are seeking to understand the general notion of tīrtha, we can but sketch in outline some of the landscape of India's tīrthas.

The great rivers of India come first to mind as tīrtha waters: Gañgā, Yamunā, Godāvarī, Narmadā, and countless others. On their banks are some of the greatest of India's sacred crossings: Prayāg and Vārāṇasī (Kāśí) on the Gañgā, Amara- 
kantaka and Tryambaka at the headwaters of the Narmadā and Godāvarī, respectively, and Srìrangam on an island in the Kāverī, to name but a few. Some of these are fords in a literal sense. Vārānasī, for instance, has been located for over 2,500 years at that ford where the ancient east-west road across north India crossed the River Gangā. So closely associated is the tìrtha with pure, running river waters that in South India the word tirtha has come to mean sacred waters.

Among mountain tìrthas the Himālayas are supreme, and their high sanctuaries, such as Badarīnāth, Kedārnāth, and Amarnāth, are sought by countless pilgrims during the summer months when they are accessible. Other mountains are tīrthas as well, such as the Vindhyas of central India or the isolated hilltops of Rājasthān crowned with temples of local goddesses, or the seven hills of Śri Venkkateśvara in Āndhra Prādesh.

Along the seacoast are such tìrthas as Puri in the east, Cidambaram and Rāmeśvaram in the south, and Dvārakā and Somnāth in the west. The circumambulation of the land of Bhārata includes these seacoast tīrthas.

Forests, too, have been places of crossing and transition. They are places of testing and trial for travelers and, since they contain the retreats and hermitages of sages, they are also places of learning and education. Both of India's great epics involve their heroes and heroines in periods of forest exile, and the adventures of the Pāṇdavas or of Rāma, Sìtā, and Lakṣmana are recalled in forest tīrthas throughout India. Most famous, perhaps, is the Naimișāranya in north India where sages recited the ancient tales to be recorded in the Epics and Purānas.

Among city tìrthas the cycle of the seven mokşa-giving cities is acclaimed: Ayodhyā, the ancient capital of Lord Rāmā; Mathurā, the old Buddhist and Jaina sanctuary and the birthplace of Lord Krṣna; Hardvār, where the Ganga enters the plains of India from the mountains; Vārānasī or Kāssĩ, the eternal city of Lord Siva on the Gañgā; Kañcī, the Vaiṣnava and Saiva city of Tamilnādu; Ujjain, the site of the great linga of Mahākāla in central India; and Dvārakā, the capital of Lord Kṛṣna in western India.

Finally, in addition to rivers and mountains, seacoasts, forests, and cities, there are the countless cycles of sites special to various sectarian groups: the fifty-one Tantric and Śāktā pitthas or "benches" of the goddesses; the twelve Saiva jyo- 
tirlingas, "lingas of light"; the several great cultic centers of Kṛșna; and the beloved places of the Śrī Vaișnavas.

The whole of India's sacred geography, with its many tìrthas - those inherent in its natural landscape and those sanctified by the deeds of gods and the footsteps of heroes-is a living geography. As such it has been central for the shaping of an Indian sense of regional and national unity. The recognition of India as sacred landscape, woven together north and south, east and west, by the paths of pilgrims, has created a powerful sense of India as Bhārat Mātā-Mother India. Pilgrims have circumambulated the whole of India, visiting hundreds of tīrthas along the way, bringing water from the Ganga in the north to sprinkle the linga at Rāmeśvaram in the far south and returning north with sands from Rāmeśvaram to deposit in the riverbed of the Gangā.

In the thousands of particular tales which attach to tīrthas everywhere and which are recounted in the mähätmyas and sthala purannas of each place, one finds repeatedly the theme of the appearance of the divine, whether as Siva, Viṣnu, Kṛnna, or the Goddess. Often, in its māhātmya, a local tīrtha will subscribe to the larger all-India tradition by linking its sanctity to the great events of the Epics and Purānas. This might be seen as the geographical equivalent of Sanskritization. The forest sojourn of the Pāndavas or the adventures of Rāma, Sìtā, and Lakșmana are especially suited to this kind of local subscription, as is the myth of the dismemberment of Satī. In this way countless local tīrthas claim their part in a larger tradition. And in each case, the stories told recount not a generalized sense of divine presence at the tìrtha, but a very particular sense of the circumstances, the crisis, the place, and the person involved in the appearance of the deity there. Every tìrtha's tale is of hierophany, the residents of heaven breaking in upon the earth.

Here the tìrtha is clearly the counterpart of the avatära. The avatära "crosses downward," opening the doorways of the divine in this world so that these thresholds might be crossed in the other direction by humans. The place of avatâra is the tìrtha, for there the crossing might be readily and safely made. For instance, because the Gangā descended in its avatarana it becomes a means of ascending as a tìrtha.

Although the particularities of tìrthas - their myths and legends, their special times and powers, their special attributes 
-are of great significance for those who visit them, their structural similarities as crossings are more significant for us in the context of this study. In what ways do these tirrthas of the earth function as crossings or fords?

First, the tìrtha māhätmyas frequently claim that the tìrtha is a good place for the performing of rites. Since it is a place of powerful and direct communication between this world and the other, the acts one does and the prayers one utters at a tìrtha are many times more beneficial and swift of fruition than they would be elsewhere. In part, of course, it is because the tìrtha, reached only after a long journey, is difficult of access (durlabha) that its rewards are multiplied. For instance, the sight (darśana) of Amarnāth, high in the Kaśmīr Himālayas, is enhanced by the sheer effort of the long trek, an effort which is rightly compared with the tapas of the ascetic. In part, however, it is the power of the place itself which is transforming. Ordinary acts of worship ( $p \bar{u} j \bar{a})$, almsgiving (dāna), and listening to the ancient lore (śravana) are charged by the extraordinary power of the place and its deity. So significant is this power that it is sometimes claimed that the place transforms even the inadvertent visitor.

On the whole, the rites performed at the tìrtha do not differ from those performed at home; it is the journey and the place itself which make the ordinary extraordinary. A few places, however, are known for distinctive rites. Especially important are those tīrthas famous for pitr tarpana and sräddha rites for the dead. Although such rites may be performed at many tīrthas, the north Indian group called the Tristhali--Prayāg, Kāsí, and Gayā-is famous for these rites. It is because the tîrtha is a good ford between this world and that of heaven or between this world and that of the pitrs that it is the right place for ritual performances. Here the tìrtha inherits some of the ritual meanings of crossing from the era of the Vedas and Brāhmanas.

Second, it is affirmed that tīrthas are not only those places where rites and sacrifices, well performed, will yield bountiful blessings, but also that tĩrthas are those places which may replace the performance of rites and sacrifices. The pilgrimage to a tīrtha, therefore, becomes a substitute for other ritual activity.

The first major Hindu treatment of tìrthayātra is in the Tīrthayātra Parva of the Mahābhārata, where the Pāndụavas, 
during their forest sojourn, undertake a circuit of the many tìrthas. On their pilgrimage, they visit the various tìrthas of rivers, mountains, and forests. A great number of these are described as bestowing the benefits of some particular sacrifice, such as the aśvamedha, the rājasūya, or the agnihotra. In the later Dharmaśāstras and Purānas, such ritual equations of tìrtha with sacrifice are common. For example, the famous Dasāśvamedha tīrtha in Vārānasī is the place where one bath bestows the fruits of "ten aśvamedhas." Of course, many ritual actions in the later tradition came to be described in terms of the sacrificial "equivalents," but none so prominently and clearly as the pilgrimage to a tirtha. Given the understanding of "crossing" which both the sacrifice and the tirtha share, this is not at all surprising. The outset of the Tìrthayātra Parva makes the equation of sacrifice and tìrthayātra quite clear in a passage which is quoted repeatedly in later centuries, both in the Purānas and in the digests of the medieval nibandhakāras:

The fruits of sacrifices, completely and accurately expounded in due order by the sages in the Vedas, cannot be obtained by the poor man, O King. Sacrifices, with their many implements and their many various requisites, are the province of princes, or sometimes very rich men, but not of single individuals who are deficient in means and implements and who do not have the help of others. But hear, O King, of that practice which is accessible even to the poor, equal to the holy fruits of sacrifice. This is the supreme secret of the sages, $O$ King: the holy practice of pilgrimage (tîrthayātra) excells even the sacrifice! $!^{36}$

Thus, it is not what one does in the tīrtha which is transforming. It is going there and being there. The tìrthayātra is the rite; the place $i s$ the power. In Vārānasī, for instance, it is said that even sleep is yoga, and even casual conversation is the repetition of the mantra.

Third, pilgrimage to a tīrtha is not only less expensive than the elaborate rites of brähmanas and kings, it is also less restrictive socially. The tìrtha might be seen, therefore, as a place where one crosses the ordinary boundaries of caste and sex. The way of the tìrtha is open and accessible to all, particularly to siudras, outcastes, and women, who are excluded from brāhmanical rites. Tìrthayātra was the mahāyāna, the "great path," of the Hindu tradition. At times in the Dharmaśāstra digests (nibandhas) the liminal status of the tirrtha beyond the boundaries of conventional life is emphasized. For instance,

${ }^{36}$ Vishnu S. Sukthankar et al., eds., Mahābhārata, 19 vols. (Poona: Bhandarkar Oriental Research Institute, 1933-59), 3.80.34-38; my translation. 
at a tìrtha the candāla, the siudra, the woman, and the brähmana all bathe in the same waters. At the tirtha the usual restrictions of touching and not touching are left behind. ${ }^{37}$ Although in practice the egalitarianism one finds in the texts has not invariably been upheld, it remains the ideal of the Dharmasiāstra tradition.

In considering Dharmaśāstric and Purāṇic statements about the accessibility of tirthas to the lower and poorer classes, it is important to remember that, to a large extent, pilgrimage originally was the tradition of these same lower classes. They certainly did not wait until pilgrimage was proclaimed the equivalent of sacrifice before taking to the roads to seek out the groves, hills, and rivers of their locative vision. One might more accurately say that the brähmanical tradition adopted and brought its own interpretive framework to the phenomenon of pilgrimage which already existed. Südras and, very likely, women as well were already veteran pilgrims. The brāhmanical treatment of tīrtha and tìrthayātra, however, brought the subject into the realm of dharma, and indeed tìrthayatra became the single most broadly elaborated subject in the Dharmaśāstric and Purānic literature as well as in the later digest literature. ${ }^{38}$

Fourth, it is commonly said of tīrthas that they are places for "crossing beyond" sins. The destruction of sins, perhaps the sins of a lifetime or of many lifetimes, is ascribed to tīrthas great and small, calling to mind some of the Vedic and Brāhmanic associations of the word tìrtha with purification. The purifying waters of a tirtha wash away one's sins, or the very dust of the place may be purifying. Entering the boundaries of a great tīrtha, such as Vārānasī, scarlet sins are said to tumble out of one's body and burn like puffs of cotton in a blazing fire. Thus, visiting the tìrtha is a kind of penance (prāyaścitta) for sins. The tale of Siva's own wandering penance is relevant here. Having sliced off the fifth head of the slander-

${ }^{37}$ Mitra Miśra, Vīramitrodaya: Tīrtha Prakāssa, Chowkhamba Sanskrit Series 239 (Benares, 1917), pp. 21-23. This discussion is in the part of his introductory section concerning those who are "qualified for pilgrimage": tīrthayātrādhikärinah.

${ }^{38}$ It is particularly in the dharmaśastra sections of the Purānas that tīrthayātra is treated, and the māhätmyas of specific tīrthas claim large sections of the major Purānas. The nibandhas are digests of Purānic and Dharmasāastra verses on diverse topics of dharma. Many of these nibandhas have entire volumes devoted to tīrthas, such as the Tīrthavivecana Kānda of Lakșmidhara's Krtyakalpataru (twelfth century); the Tīrthacintāmani of Vācaspati Miśra's Smrticintāmañi (fifteenth century); and the Tìrtha Prakāsa of Mitra Miśra's Vīramitrodaya (seventeenth century). Also important is Nārāyaṇa Bhațța's Tristhalīsetu (sixteenth century). 
ous Brahmā, Siva roamed throughout all the tīrthas of India, the skull of Brahmā clinging to his hand, until he came to Vārānasisi, which was powerful enough to destroy even the worst of great sins, brähmana slaying. There the skull fell off. In sum, the power of a tìrtha to purify sins ( $p \bar{a} p a)$ is the concomitant of its power to bestow measureless blessings (punya). In India, where the pure (pavitr) is the closest equivalent of what we call the "sacred," the purifying power of the tìrtha is very significant indeed.

Fifth, the journey to the tîrtha is both an interior and a geographical journey and the crossing is, in part, within. The pilgrim way is modeled on the paradigm of those perpetual pilgrims of India, the ascetics and renouncers. The tradition of wandering forth and leaving behind one's attachment to the stable life of household and village is the ancient way of the Hindu sannyāsins ("renouncers") and the Buddhist pravräjakas (those who have "gone forth"). On the move and unsettled except for the four months of the rainy season, these wanderers are prototypical pilgrims. In their constant visitations to the great tìrthas of the tradition, they add their own luster to that of the place itself. The lay pilgrim becomes a sannyāsin of sorts, leaving the household behind and taking up the privations and hardships of the road. The rules prescribed for the pilgrim in the Purannas and the medieval digests make it clear that the pilgrim life is an ascetic and disciplined life.

Going to a tîrtha is not only a matter of the feet, but also a matter of the heart. The mänasatìrthas, "tìrthas of the heart," are as important as the geographical tìrthas. ${ }^{39}$ The notion of these tīrthas of the heart is elaborated in the Mahābhārata as well as in the Purānas and nibandhas: truth, charity, and patience, self-control, celibacy, and wisdom-these are the tĩrthas in which one must bathe to become truly clean. If water alone were enough to purify, then the water leeches and fishes of the Gangā would all be transported to heaven. It is by bathing in the tìrthas of the heart that one may truly "cross over." The tirthas of the earth are not to be neglected, however:

${ }^{39}$ For the mānasatīrthas, see Mahābhārata, Anuśāsana Parva, 111.2-21. This passage is quoted at the outset of the Tìrthavivecana Kända of Laksmidhara (K. V. Rangaswami Aiyangar, ed., Gaekwad's Oriental Series vol. 98 [Baroda: Oriental Institute, 1942]), pp. 6-8, and also at the beginning of Miśra, Tîrtha Prakāsa, pp. 8-10. The Kásín Khanda of the Skanda Purāna (6.31-45) and the Uttara Khanda of the Padma Purāna (237.11-28) repeat the Mahābhārata version almost verbatim. 
"The one who always bathes in earthly tirthas as well as in the tìrthas of the heart goes to the supreme goal!" 40

The notion of interior tīrthas plays a perpetual counterpoint to the vast proliferation of geographical tîrthas. The refrain of the great poem on Kāśī attributed to Sañkarācārya insists: "I am that Kāsīi, whose real form is wisdom!" ${ }^{41}$ However, the valuing of the tîrthas of the heart does not replace the journey to the tirthas of the earth. Rather, the Indian tradition balances the pilgrim's faith in the sheer transforming power of the place itself with a persistent reminder that the tirtha is an internal as well as an external crossing and that the tìrtha to which one journeys is also close within. ${ }^{42}$

Finally, although most journeys to the tīrthas are related to specific vows or directed toward specific fruits, there are a few tîrthas which promise the highest goal of which the Upanișads speak: the great crossing over to the far shore of Brahman. The seven cities mentioned above are mokșadāyakāh, "bestowers of mokșa," and Hindus affirm that those who die within their borders will be liberated, never to return to the shore of birth and death. Many would say that Kāśī or Vārānasi is the most important of these seven. In any case, it is true that Kāśi is famous for death and for mokșa. The greatest of Kāśî̀'s praises is "Kāsyām maranam muktih" - "Death in Kāśî is liberation." Here we begin to glimpse the way in which India's great tîrthas inherit the wisdom traditions of crossing: crossing beyond birth and death, crossing from darkness to light, crossing from ignorance to knowledge.

In Kāsíi, it is said, Siva as guru speaks the tāraka mantra, the "ferryboat" mantra, into the ear of the dying. By its power, one is illumined with the light of Brahman (which is also the light of Kāśī, the "Luminous") and ferried across to the far shore, never to return. In the Käśi Mokṣa Nirnaya, the city is not only the luminous crossing place on the Gañā, it is also known as the threshold between heaven and earth and

${ }^{40}$ Skanda Purāna, Kāssi Khaṇda, Gurumaṇdala Granthamālāyā 20, vol. 4 (Calcutta, 1961), 6.45.

${ }^{41}$ Śñkarāeārya, Vedāntasamuccaya, ed. Brahmarși Harerāma Śarma (Bombay: Nirnaya Sāgara, 1915). For a discussion of the authenticity of Sankara's authorship, see Robert E. Gussner, Hymns of Praise (Ph.D. diss., Harvard University, 1974).

${ }^{42}$ Lakșmidhara in the Tìrthavivecana Kānda of the Krtyakalpataru is especially concerned to balance the interior and the ritual aspects of pilgrimage; $K$. V. Rangaswami Aiyangar, ed., Gaekwad's Oriental Series vol. 98 (Baroda: Oriental Institute, 1942). 
the crossing place within, called the atman. It is said to be located "where the nose and eyebrows meet." 43 The radical spiritual crossing expressed by the use of tr/tarati in the Upanișads has clearly become a part of the later tradition of tīrtha and tīrthayātra. As Siva exclaims in the Kāś Rahasya while showing his beloved place to Parvatī: "Look dear! Look at Kāśi - a boat set for the crossing, a motionless refuge, set just above the earth, a boat not of wood and nails, but the illuminer of all people, whom she carries across the sea of being." 44

\section{THE Tìrtha AS SYMBOL}

Traveling to the tìrthas is one of the most prominent forms of popular piety in India today. The past century of modernization has served further to stimulate pilgrim travel, enabling Indians by the millions each year to take to the pilgrim road by buses and trains. While all of India's tirthas are no longer "difficult of access" (durlabha), it would be safe to say that they are more popular and, in a sense, more powerful than ever before. As Yudhișthira once said to the wise Vidura, who had returned from a tìrthayatra, "Devotees like you, who have become tīrthas (tìrthabhütāh) themselves, are the ones who make the tìrthas into tīrthas (tīrthīkurvanti tīrthāni) by embodying the presence of God there." 45 With their great numbers and the power of their cumulative devotion, India's pilgrims are continually making their tīrthas into tīrthas.

The significance of tīrthas in India may be understood, as I have attempted to do here, by taking account of the many strands of the Indian tradition which have converged in the tīrtha: the popular locative traditions of folk piety, the sacrificial and ritual traditions of crossing between heaven and earth, and the wisdom traditions of crossing to the far shore of the river of samsāra. Since tīrthas have accumulated all these traditions, they are sought by people with wide-ranging religious aspirations-from healing to mukti. For some, the tīrtha

${ }^{43}$ The Kās̄i Mokşa Nirnaya, also called the Kāss Mrti Mokşa Vicāra, is attributed to Sureśvarācārya and quotes, in this matter, the Jābala Upanișad 1-2. See Pt. Ambika Datta Upādhyāya, Hindi trans, Kāśñ Mokşa Nirnaya (Gorakhpur: Śrī Gaurísankar Ganerivālā, 1931); or Gopināth Kavirāj, ed., Kāssī Mrti Mokşa Vicāra, The Prince of Wales Sarasvati Bhavana Text no. 67 (Allahabad: Government Printing Office, 1936).

${ }^{44}$ Kāsin Rahasya: Brahmavaivarta Purāṇa Parisișța, Gurumanḍala Granthamālāyā no. 14, vol. 3 (Calcutta, 1957), 3.21.

${ }_{45}$ C. L. Goswami, trans., Śr̄mad Bhāgavata Mahāpurāna, with Sanskrit text and English translation (Gorakhpur: Gita Press, 1971), 1.13.10. 
has long been associated primarily with boons and blessings, such as health, longevity, and fertility. For others, the tirtha is the place where brāhmanical rites and observances are to be performed. And for a few, the tītha is the place where one leaves behind all desires and all rites and sets out for the far shore of mokşa. Even those who have placed little value upon brāhmanical traditions of tîrthayātra have utilized the notion of the tìrtha to refer to interior crossings, and the Gangā, the Yamunā, and Kāsis have been given mystical locations in the subtle physiology of the body. ${ }^{46}$

The river, the crossing, and the far shore have formed an important symbolic complex in the Indian imaging of transition and transcendence. While the word employed in speaking of such passages may not always derive from the $t \bar{r}$ root, the specific image of fording the river flood to the far shore remains a key image and is utilized in a variety of contexts. For example, the dead are said to cross the river Vaitarani to the world of Yama, or the sacrificer crosses to the world of heaven on the "ships" 47 of sacrifice, or the seeker crosses on the raft of dharma to the far shore of nirvana. Samsāra, the stream of life and death and life again, entails one crossing after another. Indeed, in one of the creation accounts of the Satapatha Brāhmana, no sooner has the creator Prajāpati emerged from the primordial egg to begin laboring over creation, than he sees the far shore ( $p \bar{a} r a)$ of his own life, "as one might see in the distance the opposite shore" of a river. ${ }^{48}$ The $p \bar{a} r a$, the "far shore," may be simply the "other" or the "opposite" shore, whether that is the world of heaven, or the realm of death beyond the Vaitaranī. However, pära also means the "farthest limit" or the "fullest extent," the ultimate. To have crossed over to that shore is to have gone as far as one can go. Thus, for some, the far shore is not death, nor heaven, but the land described as mokṣa or nirvāna. In both the Advaita and Mādhyamika schools of philosophy, one sees, from the perspective of the far shore beyond duality, that it is not different from "this shore."

${ }^{46}$ See Mircea Eliade, Yoga: Immortality and Freedom, trans. Willard R. Trask, Bollingen Series 61, 2d ed. (Princeton, N.J.: Princeton University Press, 1969), pp. 227 ff.; see also Käśi Mokşa Nirnaya.

${ }^{47}$ See, e.g., Aitareya Brāhmana 1.3.13 and Satapatha Brāhmana 4.2.5.10. for references to the sacrifice as a "ship."

${ }^{48}$ Satapatha Brähmana 11.1.6.6. and, similarly, when the gods are born, 11.1.6.15. 
While the goal is the pära, variously conceived, the means of crossing over may be the tîrtha, the ford, or it may be the ladder (sopāna) or the bridge (setu). Especially the ladder image vividly reminds us that the symbolism of crossing is also the symbolism of ascent. As the work of Mircea Eliade on yoga and shamanism has so clearly demonstrated, the mystical crossing may be imaginatively described as an ascent "upward" on a ladder to heaven, or a crossing "over" on a perilous bridge, or it may be described primarily in terms of the interior ascent of the yogin through the worlds of the inner cosmic landscape. ${ }^{49}$

From its common usage in India today, it would be tempting to call the tīrtha a "sacred" place. Indeed, in later Sanskrit, the adjective tintha is sometimes given as "sacred," and the verbal form tìrth $i+k r$ is said to mean "to sanctify." ${ }_{50}$ However, "sacred" is surely a conceptual category which needs some serious rethinking in its applicability to the Hindu universe. This study of both the ancient and modern implications of the term tîrtha has shown it to have dynamic and transitive connotations more accurately conveyed by "ford" or "crossing place." As such, the term tīrtha may be useful in building a comparative conceptual vocabulary for pilgrimage and passage. The understanding of India's "sacred" places may be enlarged and enriched by seeing them, not as destinations, but as fords, where caste and sex, sins, sickness, and death, and even samsāra itself, may be transcended in the crossing.

\section{Harvard University}

${ }^{49}$ Eliade, Yoga: Immortality and Freedom; Mircea Eliade, Shamanism: Archaic Techniques of Ecstasy, trans. Willard R. Trask, Bollingen Series 76 (Princeton, N.J.: Princeton University Press, 1964), esp. chaps. 8 and 13; see also Dona Luisa Coomaraswamy, "The Perilous Bridge of Welfare," Harvard Journal of Asiatic Studies 8, no. 2 (August 1944): 196-213.

${ }^{50}$ Vaman Shivram Apte, The Practical Sanskrit-English Dictionary, rev. ed. (Poona: Prasad Prakashan, 1957). 